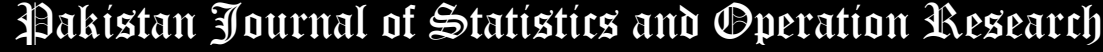

\section{Evaluation of Impact of Success Factors of Supply Chain Strategy and Flexibility on Supply Chain Performance}

\author{
Amit Chandak ${ }^{*}$, Sumit Chandak ${ }^{2}$, A. Dalpati ${ }^{3}$ \\ * Corresponding Author \\ 1. IPS Academy , Institute of Engineering \& Science, Indore (M.P.), India, amit 2269@yahoo.com \\ 2. Shri Vaishno Vidyapeeth Vishwavidyalaya, Indore (M.P.), India, sumichandak@gmail.com \\ 3. Shri Govindram Seksaria Institute of Technology and Science, Indore (M.P.), India, adalpati89@gmail.com
}

\begin{abstract}
Due to rapid globalization, an introduction of Goods and Services Taxes (GST), ban on BS-III vehicles, and rapid technological advancement creates new dimensions for the automobile industry in India especially for those who come in the category of small and medium enterprise (SMEs).In the current changing scenario victorious execution of supply chain management (SCM) practices can provide competitive leverage to Automobile manufacturers over their rivals particularly those who are poorly implemented supply chain management practices. This paper takes two main SCM practices, i.e. supply chain flexibility (SCF) and supply chain strategy (SCS).Against this background, this paper acknowledged 5 success factors (SFs) for supply chain flexibility and 3 success factors (SFs) for supply chain strategy for proper implementation of SCM practices in the Automobile industry, and studied their impact on three factors of supply chain performance (SCP), and thereby on firms performance. The top management of any industry is focused on their core strength with commitment, long-term vision and provides resources for supply chain, and thereby developing effective and efficient SCS emerged as the most significant SFs. To measure the impact on supply chain performance, the author carefully measures different SFs of SCS related to customer-oriented strategy, innovation strategy and agile supply chain strategy on cost performance, logistics performance and customer satisfaction performance. Similarly to access the impact on supply chain performance, carefully measure different SFs of SCF on cost performance, logistics performance and customer satisfaction performance. Results are analyzed by testing research propositions using standard statistical tools like reliability analysis, correlation analysis and regression analysis using SPSS-23.
\end{abstract}

Key Words: Supply Chain Flexibility (SCF), Supply Chain Performance (SCP), and Supply Chain Strategy (SCS), Success Factors (SFs)

\section{Introduction}

The economic growth of any developing nation depends principally on the availability of key resources and manpower. In India, the economic growth is greatly influenced by automobile industry which shown significant growth and proven to be one of the fastest growing and one of the strongest drivers of technology, growth, and employment (Gottschalk and Kalmbach, 2007).To effectively compete in the global scenario the industry concentrated on the operational effectiveness with the efficient and effective implementation of SCM practices (Singh, Garg \& Deshmukh, 2010). Before liberalization, the Indian companies work in a protected environment and the business runs by several big players under Monopolistic and Restrictive Trade Practice under MRTP Act, 1969. Economic liberalization creates opportunities for overseas players to invest in the country and collaborated with a local player. After liberalization due to rapid advancement and emerging trends opens a new era for Indian Automaker (Choudhary and Goyal, 1997). The Indian auto industry is one of the fast-growing industries in the world and accounts for 7.1 percent of the country's Gross Domestic Product (GDP). However, Indian auto industry facing many challenges from global competition (Singh, Garg, \& Deshmukh, 2008a).To overcomes these challenges the 
industry should have collaboration with their clientele and suppliers and should remain competitive in terms of cost, quality, and delivery. Due to these challenges, the appropriate implementation of supply chain management (SCM) practices can play a vital role in the success. Effective supply chain strategy and supply chain flexibility can ensure the successful implementation of SCM practices. In this paper, the authors have identified 3 SFs for SCS and 5 SFs for SCF from literature in order to find the effects of the SCM initiatives taken by Indian companies on their performance. The performance measures included are cost performance, customer satisfaction performance, and logistics performance. This paper has been organized as follows: The second part shows the literature review and identification of SFs. The third part discusses research objectives and methodology. In the fourth part discussed about the questionnaire-based survey. The fifth part discusses correlation and regression analysis for testing of research propositions. Finally, the sixth part discusses concluding remarks

\section{Literature Review and Identification of SFs}

In today's fast-growing market the proper implementation of supply chain management in the auto industry, are facing tremendous challenges on a daily basis. With the supply chain being at the core of business operations, these challenges can directly affect the manufacturers in substantial ways. Now a day's in competitive business environment supply chain management has been becoming increasingly important. To compete in such a competitive situation industry must adopt an appropriate supply chain management strategy. Supply chain strategy is a function of product and process. Every product is unique for the company and required specific supply chain strategies. Strategy for any product/service depends on supply/demand uncertainty, product lifecycle and manufacturing strategies. Due to these uncertainties, different supply chain strategies are in practice (Lee, 2002). Hence, setting the accurate SC strategy is necessary in order to compete in the market and must need the strategy that integrates and coordinate right through the supply chain to produce the performance of supply chain members (Cohen and Roussel, 2005) Firms must need to those strategies that favor both its product and marketplace (MasonJones et al.2000). According to Fisher (1997), the primary footstep in developing the supply chain strategy is to know the demand pattern of the product. Towill and Christopher (2002) Proposed that there are three types of SCS: agile supply chains; lean supply chains; and hybrid supply chains. Sufian, 2010 argued that the IT (Information Technology) is one of the important criteria that should facilitate in implementing the business strategy. For taking competitive advantages strategies as per customer conveniences such as customized logistics and agility increase demand while strategies on the operational side and lean network increase supply-side capabilities (Morash 2001).From the literature review, the author examined the critical factors that influence supply chain strategy for organizations in managing their supply chains; in their study, the authors determined three SFs in SCS these factors are innovative strategy, customer oriented strategy and agile supply chain strategy. Flexibility is a multifaceted and multidimensional concept (Sethi and Sethi 1990; Upton 1994, 1995). Due to this reason, different flexibility definitions and dimensions are available but there is no uniform concept that is broadly accepted. The concept of flexibility has been first introduced into the economics literature by Stigler in the 1939s, in the context of a firm's ability to accommodate greater variations in the demand output (Carlsson1989; De Toni and Tonchia 1998, 2005). From the literature review the author examined the critical factors that influence supply chain flexibility for organizations to managing their supply chains; in their study, the authors determined five SFs in SCF, these factors are innovative \& new product flexibility, process flexibility, existing product flexibility, delivery flexibility and information flexibility.

Supply chain performance is a vital and multi-faced rapidly developing area of research in supply chain management. It is defined as the "information concerning the processes and products results that permit the assessment and the comparison in relation to goals, patterns, past results and with other processes and products" (Petrovic-Lazarevic and Sohal 2002). It is vital to recognize those determinants that force supply chain success. To attain an efficient and effective supply chain, many companies have realized the connotation of performance assessment and what measures should be used. The goals of performance measurement are to improve the efficiency and effectiveness of a supply chain (Beamon 1999; Gunasekaran et al. 2001). The organizational performance refers to how well an organization acquires its market-oriented goals, financial goals in terms of performance items such as return on assets (ROA), market share and growth rate(Vickery et al. 1991). In supply chain performance quality, cost, response time and service level are the performance indicators (Christopher and Towill, 2001). Lippman 
(2001) identified the effect of product cycle time, due date performance, cost, and quality on operational performance.

\section{Research Objectives and Methodology}

This paper is an empirical study for identification of SFs of supply chain strategy and flexibility for implementation of SCM and focuses on their effects on the performance of the Indian automobile industry. Eight SFs of SCS and SCF are identified from the extensive literature review and experts' opinions, and their upshot has been studied on different categories of performance measures; these categories are cost performance, customer satisfaction performance and logistic performance and thereby firms performance. Based on this, the study has attempted to test the following three research null hypothesis.

H01: There is no significant relationship between SFs of SCS and SCF with cost performance.

H02: There is no significant relationship between SFs of SCS and SCF with customer satisfaction performance.

H03: There is no significant relationship between SFs of SCS and SCF with logistics performance.

The present research developed the following framework (Fig. 1) and tried to validate it in the current study. According to this framework, SFs of SCM implementation leads to performance improvement of Indian automobile industry.

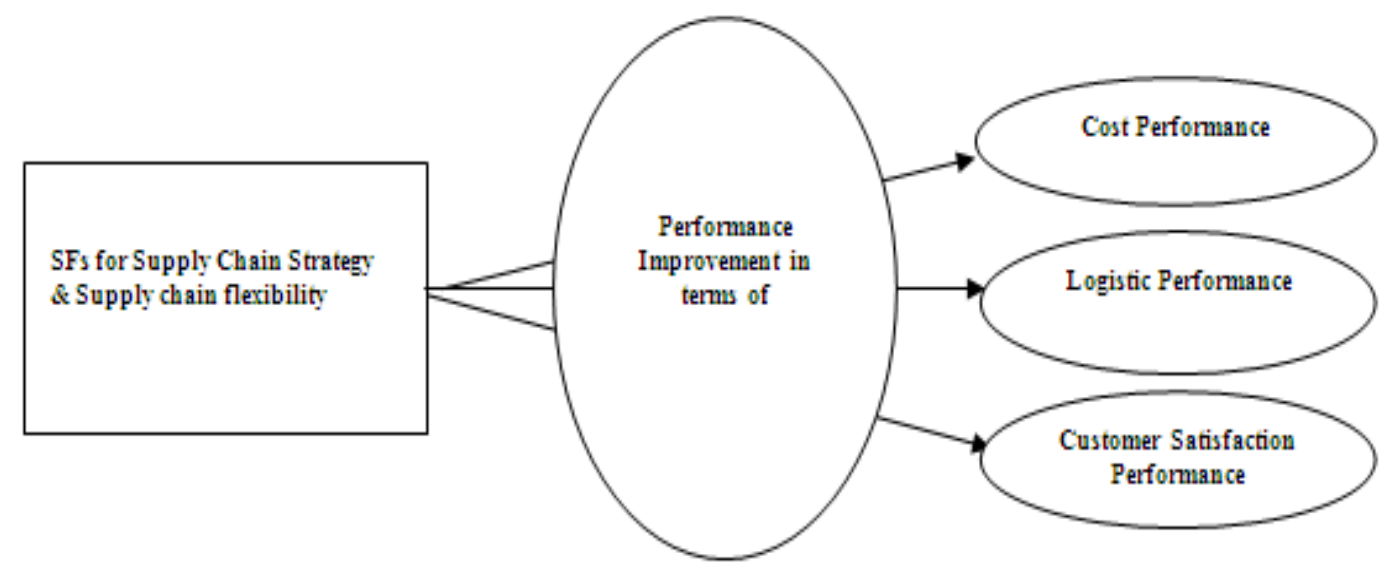

Figure 1 Framework for the study.

In order to test the research hypothesis and for analysis of different issues related to SCM and performance, a survey instrument was developed. The survey was conducted among 211 respondents selected from Indian automobile manufacturers out of which 199 responses find suitable for further processing. Although the questionnaire was sent by post or e-mail for the final survey at the end of the survey questionnaire, respondents were requested to fill their profile details, but it was optional. The questionnaire contained three main parts: Part A focused on SFs for implementation of SCS, and Section B focused on SFs for SCF and the final part C focuses on performance improvement. (Questionnaire Attached in appendix)

\section{Findings from Questionnaire-Based Survey}

The mean, standard deviation (SD) ,t-value and Cronbach's Alpha for SFs of SCS and SCF was analyzed through statistical methods using SPSS-23. 


\section{SFs for SCS, SCF}

\begin{tabular}{|l|l|c|c|c|c|}
\hline \multicolumn{7}{|l|}{ Table 1 Success Factors for SCS and SCF implementation. } \\
\hline S.No & Success Factor & Mean & S.D. & t-value & $\begin{array}{l}\text { Cronbach's } \\
\text { Alpha }\end{array}$ \\
\hline 1 & Innovative Strategy & 4.407 & 0.512 & 8.736 & 0.767 \\
\hline 2 & Customer Oriented Strategy & 4.378 & 0.606 & 6.865 & 0.880 \\
\hline 3 & Agile Supply Chain Strategy & 4.376 & 0.552 & 7.501 & 0.831 \\
\hline 4 & $\begin{array}{l}\text { Innovation \& New product / Future } \\
\text { Research Flexibility }\end{array}$ & 4.345 & 0.628 & 6.044 & 0.889 \\
\hline 5 & $\begin{array}{l}\text { Sourcing Flexibility \& Process } \\
\text { Flexibility }\end{array}$ & 4.297 & 0.572 & 5.717 & 0.882 \\
\hline 6 & Existing Product Flexibility & 4.219 & 0.543 & 4.453 & 0.850 \\
\hline 7 & $\begin{array}{l}\text { Trans-Shipment and Delivery } \\
\text { Flexibility }\end{array}$ & 4.407 & 0.561 & 7.985 & 0.882 \\
\hline 8 & Information Flexibility & 4.371 & 0.508 & 8.051 & 0.841 \\
\hline
\end{tabular}

Source: SPSS-23 results

\section{SFs of SCP}

Performance measurement in the supply chain can be defined as the process of quantifying the effectiveness of various processes being followed in the supply chain. Performance measurement provides the information necessary for decision makers to plan, control, and direct the activities of the supply chain process. This study has selected the performance measures cost, customer satisfaction and logistic parameters for assessment of the performance of the supply chain.

\section{Performance Improvement In Terms of Cost Parameters}

On the basis of extensive literature review and expert opinion, 5 parameters of cost performance are identified and asked from respondents. These parameters are: return on investment, return on investment growth rate, market share, return on sales \& return on sales growth. The average improvement in performance in the past three years was measured on a Likert scale of five (1- low, 5- high). In this study five parameters identified and result as follows return on investment (4.42), return on investment growth rate (4.55), market share (4.29) increased in export segment, return on sales (4.50) is a big concern for industry and return on sales growth (4.19) is always a problem in Indian automobile SMEs. Findings also show that cost performance of Indian SMSs has improved least in terms of sales growth and market share.

\section{Performance Improvement in Terms of Logistic Parameters}

On the basis of extensive literature review and expert opinion, 4 parameters of logistic performance are identified. These parameters are reduced warehouse costs, reduced obsolescence, faster order processing speed and reduced inventory at all sites of the supply chain. The average improvement in performance in the past three years was measured on a Likert scale of five (1- low, 5- high).The findings show that reduced warehouse cost(4.11) is not a major problem for automakers, reduced obsolescence(4.50) is a major issue for industry due to limited fund availability. Further findings show that faster order processing (4.21) is major concerned due to lack of availability of skilled labor and latest machines. At the last finding show that reduced inventory (4.40) are major problems for automobile industry due to rapid changes in product variety and reduced life cycle of the product. 


\section{Performance Improvement in Terms Customer Satisfaction Parameters}

On the basis of extensive literature review and expert opinion, 5 parameters of customer service and satisfaction are identified. These parameters are: response time to customer query time, level of customer perceived value of the product, level of service systems to meet particular customer needs, customer satisfaction and provide the quality product at least cost. The average improvement in performance in the past three years was measured on a Likert scale of five (1- low, 5- high). The findings show that response time to a customer complaint (with the mean value of 4.29) has considerable improvement in recent years, this is followed by the level of customer perceived value of the product (4.22) companies try to make the product which gives more value to customers. Further analysis shows that level of service system to meet customers need (4.36) need to improve further, the market is now more customer oriented and in order to satisfy customers (4.66), it is important to resolve their complaints quickly. At the last findings regarding customer satisfaction and provide the quality product at least cost (4.50) requires more innovation and companies in India lacking in innovation.

\section{Correlation and Regression Analysis for Testing of Research Hypothesis}

In earlier sections, the study has tried to deal with issues associated to Success Factors (SFs) of supply chain strategy and flexibility and supply chain performance and thereby addressing the business performance of Indian auto makers. The main research hypotheses the present study are concerned with the relationship between SFs of supply chain strategy and flexibility and improvement in performance on different categories. For testing of research hypothesis made in this study, correlation and regression analysis has been carried out in this section. The results are given in Table 2 and Table 3.

\begin{tabular}{|l|l|l|l|l|}
\hline \multicolumn{6}{|l|}{ Table 2 Pearson Correlation and regression analysis of SFs of SCS with SCP issues. } \\
\hline S.No. & \multicolumn{1}{|c|}{ SFs } & $\begin{array}{l}\text { Correlation coefficient for } \\
\text { cost performance }\end{array}$ & $\begin{array}{l}\text { Correlation } \\
\text { coefficient for logistic } \\
\text { performance }\end{array}$ & $\begin{array}{l}\text { Correlation coefficient } \\
\text { for customer } \\
\text { satisfaction } \\
\text { performance }\end{array}$ \\
\hline 1 & Innovative Strategy & $0.892^{* *}$ & $0.356^{* *}$ & $0.332^{* *}$ \\
\hline 2 & Agile Supply Chain Strategy & $0.778^{* *}$ & $0.406^{* *}$ & $0.434^{* *}$ \\
\hline 3 & Customer Oriented Strategy & $0.474^{* *}$ & $0.352^{*}$ & $0.367^{* *}$ \\
\hline & $\begin{array}{l}\text { Adjusted R (Regression } \\
\text { Result) }\end{array}$ & 0.360 & 0.169 & 0.189 \\
\hline & F-Value & $21.985^{* *}$ & $7.952^{* *}$ & $9.090^{* *}$ \\
\hline
\end{tabular}

$*$ p value $<0.05, * *$ v value $<0.01$

- Success Factors for new product flexibility implementation have a strong correlation with cost performance. This implies that new product flexibility is necessary for companies. But innovative \& new product flexibility was moderately correlated with logistic performance and customer satisfaction performance.

- Success Factors for process flexibility implementation have a significant correlation with cost performance and logistic performance and have a weak correlation with customer satisfaction performance.

- Success Factors for delivery flexibility implementation have a strong correlation with cost performance, logistics performance, and customer satisfaction performance.

- Success Factors for existing product flexibility implementation have a significant strong correlation with cost performance and logistic performance but and has a significant correlation with customer satisfaction performance. This implies that an existing product fulfills the need of the customer if some modification can be imparted in product. But EPF has weak correlation with customer satisfaction performance implies that customer wants new and innovative products.

- Success Factors for information flexibility implementation have a strong correlation with cost performance and logistic performance but it has weak correlation with customer satisfaction performance. 


\begin{tabular}{|c|l|l|l|l|}
\hline \multicolumn{3}{|c|}{ Table 3 Pearson Correlation and regression analysis of SFs of SCF with SCP issues. } \\
\hline S.No. & \multicolumn{1}{|c|}{ SFs } & $\begin{array}{l}\text { correlation } \\
\text { coefficient for } \\
\text { cost performance }\end{array}$ & $\begin{array}{l}\text { correlation coefficient } \\
\text { for logistic } \\
\text { performance }\end{array}$ & $\begin{array}{l}\text { corration coefficient } \\
\text { for customer } \\
\text { satisfaction } \\
\text { performance }\end{array}$ \\
\hline 1 & New Product flexibility & $0.652 * *$ & $0.573 * *$ & $0.457 * *$ \\
\hline 2 & Process Flexibility & $0.846^{* *}$ & $0.677 * *$ & $0.462 * *$ \\
\hline 3 & Delivery Flexibility & $0.830 * *$ & $0.677 * *$ & $0.574 * *$ \\
\hline 4 & Existing Product Flexibility & $0.814 * *$ & $0.782 * *$ & $0.426^{* *}$ \\
\hline 5 & Information Flexibility & $0.786 * *$ & $0.792 * *$ & $0.377 * *$ \\
\hline & Adjusted R2 (Regression Result) & 0.828 & 0.695 & 0.337 \\
\hline & F-Value & $110.847 * *$ & $52.465^{* *}$ & $11.716^{* *}$ \\
\hline
\end{tabular}

$* p$ value $<0.05, * * p$ value $<0.01$

\section{Conclusion}

Some of the comments on the basis of this analysis are as follows:

- Success Factors for innovative strategy implementation have a significant correlation with cost performance. This implies that an innovative strategy is costlier for companies. The innovation can significantly improve the performance. But innovative strategy weak positive correlated with logistic performance and customer satisfaction performance, with the help of innovative product companies can satisfy their customers.

- Success Factors for agile supply chain strategy implementation have a significant correlation with cost performance but has a weak correlation with logistic and customer satisfaction performance.

- Success Factors for the customer-oriented strategy was moderately correlated with cost performance because the customer wants a quality product, this strategy has a weak correlation with logistic performance and customer satisfactory performance.

The objective of this study was to identify the impact of SFs for SCM strategy and SCM flexibility on the performance of Indian automobile industry in the context of the emerging global market. From this study, it is observed that the Success Factors (SFs) for SCM strategy and SCM flexibility have a positive impact on different categories of performance such as cost performance, logistics performance, and customer satisfaction performance and thereby on business performance of Indian companies. Further, analyzed different SFs show different impacts on different performance criteria. It is also observed that to face the challenges of a global market, companies in India are now recognizing the importance of SCM practices implementation on a larger scale. On the basis of this study, some of the concluding observations are as follows:

- Top management commitment development of effective SCM strategy is the main SFs for implementation of SCM in Indian companies.

- The effective SCM strategy is the main SFs for implementation of SCM are the long-term vision for survival and growth.

- In customer-oriented strategy, improvement has been observed in terms of ability to resolve customer complaints, the ability to deliver the product on time, ability to follow up customer inquiries and ability to determine future expectations of customers.

- In innovation strategy improvement has been observed in terms of ability to implement new technology, ability to respond well to customer demand for new features, ability to fight competitors on quality and price.

- Indian companies have performed better in the last three years in terms of net profit, return on investment, and revenue growth.

- Companies should develop and apply their supply chain flexibility effectively after analyzing the business environment and their future plans. 


\section{Limitations of the Study}

There are a number of factors that limits and control the study and its generalibility. First, this Study is done only on Indian automobile industry which is one of the limitations. Due to single-sector study hence the conclusions may not be accepted to other sectors but it provides instructional guidelines for multiple industries and sector. This study would add to the understanding of supply chain performance. Second, the sample selection was based on a convenience sample, rather than a random probability sample, which is often used for investigative job (Zikmund, 2003). Third, the sample represented a restricted number of companies in a single sector industry. Fourth, the study is based on a questionnaire which leads to a possibility of respondents answering questions as per their understanding. Supply chain performance is an important area for a researcher in the supply chain management field. The main goal of performance measurement is to improve the efficiency and effectiveness of a supply chain .

\section{Acknowledgements}

This research is based on my Ph.D work under the guidance of Dr. A Dalpati, Professor., SGSITS, Indore. Their supports have been fully acknowledged. We finally acknowledge the reviewers for their helpful comments and suggestions

\section{References}

1. Beamon,B.M,(1999) "Measuring supply chain performance" International Journal of Operations \& Production Management, Vol. 19 No. 3, 1999

2. Choudhary, R. and Goyal, A. (1997) "The Automobile Industry in India. Journal of Jagan Institute of Management Studies, April- June issue, pp. 75-83.

3. Cohen, S., \& Roussel J. (2005) "Strategic Supply Chain Management: The Five Disciplines for Top Performance". New York: McGraw-Hil.

4. Carlsson, B. (1989), "Flexibility and the theory of the firm", International Journal of Industrial Organization, Vol. 7, No. 2, pp. 179-203

5. De Toni, A. and Tonchia, S. (1998), "Manufacturing flexibility: a literature review", International Journal of Production Research, Vol. 26, No. 6, pp. 1587-1617

6. De Toni, A. and Tonchia, S. (2005), "Definitions and linkages between operational and strategic flexibilities", Omega, Vol. 33, No. 6, pp. 525-540.

7. Fisher, M. (1997) "What is the right supply chain for your product?" Harvard Business Review, 75(2), $105 \mathrm{e} 116$

8. Gottschalk, B. and Kalmbach, R. (2007) "Mastering Automotive Challenges". Kogan Page, London.

9. Lee,H.L.,2002, "Aligning Supply Chain Strategies with Product Uncertainty", IEEE Engineering Management Review, 44(2):26 - 26 · February 2003.

10. Lippman (2001) "Supply Chain Environment Management" First published: 26 December 2001 https://doi.org/10.1002/tqem.1301.

11. Mason-Jones, Ben Naylor \&Denis R. Towill, (2000) "Lean, agile or leagile? Matching your supply chain to the marketplace" International Journal of Production Research, Vol.38

12. Morash, E.A, (2001) "Supply chain strategies, capabilities, and performance", Transportation Journal; Fall $2001 ; 41$

13. Petrovic-Lazarevic, S, Sohal A. (2007), "Supply chain management performance in the Australia manufacturing industry", available; www. buseco.monash.edu.au/mgt/research/working papers/2007/ wp 21 07.pdf.

14. Singh, Garg, \& Deshmukh,( 2008a), "Challenges and strategies for competitiveness of SMEs: a case study in the Indian context", International Journal of Services and Operations Management (IJSOM), Vol. 4, No. 2, 2008.

15. Singh, R. K., Garg, S. K., \& Deshmukh, S. G. (2010) "Strategy development by Indian SSIs", Industrial Management \& Data Systems, 110(7), 1073e1093.

16. Sethi, A. K. and Sethi, S. P. (1990), "Flexibility in manufacturing: A survey", International Journal of Flexible Manufacturing Systems, Vol. 2, No. 4, pp. 289-328. 
17. Stigler, G, (1939), "Production and distribution in short run" The political Economy, Vol.47, No.3, pp.305327.

18. Towill and Christopher (2002) "Developing Market Specific Supply Chain Strategies",International Journal of Logistic Management, Vo.13, Issue 1.

19. Upton, D. M. (1995), "Flexibility as process mobility: the management of plant capabilities for quick response manufacturing", Journal of Operations Management, Vol. 12, No. 3-4, pp. 205-224.

20. Upton, D. M. (1994), "The management of manufacturing flexibility", California Management Review, Vol. 36, No. 2, pp. 72-89.

21. Vickery, S. N., Calantone, R. and Droge, C. (1999), "Supply chain flexibility: an empirical study", The Journal of Supply Chain Management, Vol. 35, No. 3, pp. 16-24.

22. Zikmund (2003), "Business Research Methods", Business \& Economics, 7 th Edition.

\section{Appendix}

\section{Questionnaire}

General Information: About Your Company (Optional)

Name of Employee

Age

Qualification

Organizations Name

Job/Position

You're Experience

No. of Employee's

Approx.Turnover
:

:

:

$:$

Manufacturing plant in one state/ more than one state (Please tick)

\section{Part A}

SFs for Supply Chain Strategy(SCS)

Please indicate the importance of each item on following points in achieving organizations supply chain strategy.

Innovative Strategy

\begin{tabular}{|c|l|l|l|l|l|l|}
\hline 1 & Rate of new product advancement/ innovation & 1 & 2 & 3 & 4 & 5 \\
\hline 2 & $\begin{array}{l}\text { Providing high value service along with the core products or services already } \\
\text { being offered }\end{array}$ & 1 & 2 & 3 & 4 & 5 \\
\hline 3 & Developing core competencies by new knowledge and research & 1 & 2 & 3 & 4 & 5 \\
\hline 4 & Using power of existing knowledge ,ability and resources & 1 & 2 & 3 & 4 & 5 \\
\hline
\end{tabular}


Customer Satisfaction Strategy

\begin{tabular}{|l|l|l|l|l|l|l|}
\hline 1 & Providing quality products and services & 1 & 2 & 3 & 4 & 5 \\
\hline 2 & Offering modular parts in competitive price & 1 & 2 & 3 & 4 & 5 \\
\hline 3 & Using power of existing knowledge, ability and resources & 1 & 2 & 3 & 4 & 5 \\
\hline 4 & Using Standard accessories and parts & 1 & 2 & 3 & 4 & 5 \\
\hline
\end{tabular}

Agile Supply Chain Strategy

\begin{tabular}{|c|l|l|l|l|l|l|}
\hline 1 & Adopting latest SCM concepts and tools & 1 & 2 & 3 & 4 & 5 \\
\hline 2 & Effective planning of long-term MPS and MRP & 1 & 2 & 3 & 4 & 5 \\
\hline 3 & $\begin{array}{l}\text { Design of supply chain across the production system and outside the production } \\
\text { system }\end{array}$ & 1 & 2 & 3 & 4 & 5 \\
\hline 4 & Close partnership with suppliers with technological support & 1 & 2 & 3 & 4 & 5 \\
\hline 5 & Appropriate mode of transportation & 1 & 2 & 3 & 4 & 5 \\
\hline
\end{tabular}

\section{Part B}

\section{SFs for Supply Chain Flexibility(SCF)}

Innovation \& New product / Future Research Flexibility

\begin{tabular}{|c|l|l|l|l|l|l|}
\hline 1 & $\begin{array}{l}\text { Changing in existing product and development of number of new products per year } \\
\text { at reasonable pricing }\end{array}$ & 1 & 2 & 3 & 4 & 5 \\
\hline 2 & Reducing lead time & 1 & 2 & 3 & 4 & 5 \\
\hline 3 & $\begin{array}{l}\text { Faster delivery to customer/manufacturer which leads to better relationship with } \\
\text { them }\end{array}$ & 1 & 2 & 3 & 4 & 5 \\
\hline 4 & Involving vendors and suppliers in development of new product & 1 & 2 & 3 & 4 & 5 \\
\hline 5 & Creation of new products by use of PLM ( CAD software/ Analysis tools) & 1 & 2 & 3 & 4 & 5 \\
\hline 6 & Development of new product in parallel to existing product at reasonable cost & 1 & 2 & 3 & 4 & 5 \\
\hline 7 & Better synchronization of operations in SC for development of new product & 1 & 2 & 3 & 4 & 5 \\
\hline
\end{tabular}

Sourcing Flexibility\& Process Flexibility

\begin{tabular}{|c|l|l|l|l|l|l|}
\hline 1 & Managing reasonably the cost of switching from one supplier to another & 1 & 2 & 3 & 4 & 5 \\
\hline 2 & Association with suppliers in managing the changing situation & 1 & 2 & 3 & 4 & 5 \\
\hline 3 & Creating Flexible organization in order to meet variety of customer and supplier & 1 & 2 & 3 & 4 & 5 \\
\hline 4 & $\begin{array}{l}\text { Creating better relationship with supplier and customer in order to manage changing } \\
\text { environment }\end{array}$ & 1 & 2 & 3 & 4 & 5 \\
\hline 5 & Order size and frequency of delivery may vary depend on demand & 1 & 2 & 3 & 4 & 5 \\
\hline 6 & $\begin{array}{l}\text { Managing close coordination between outside and inside activities in Supply Chain } \\
\text { by providing intensive distribution }\end{array}$ & 1 & 2 & 3 & 4 & 5 \\
\hline 7 & Launching of new product at right time in market & 1 & 2 & 3 & 4 & 5 \\
\hline
\end{tabular}

Existing Product Flexibility

\begin{tabular}{|l|l|l|l|l|l|l|}
\hline 1 & Change and modification in features and specifications of existing products & 1 & 2 & 3 & 4 & 5 \\
\hline 2 & Managing the available different designs from standard modules & 1 & 2 & 3 & 4 & 5 \\
\hline 3 & Modifying Existing product configurations as per Customer need & 1 & 2 & 3 & 4 & 5 \\
\hline 4 & Reducing set up time and machining time & 1 & 2 & 3 & 4 & 5 \\
\hline
\end{tabular}


Trans-Shipment and Delivery Flexibility

\begin{tabular}{|c|l|l|l|l|l|l|}
\hline 1 & Movement of stock between locations should be changing as per requirement & 1 & 2 & 3 & 4 & 5 \\
\hline 2 & $\begin{array}{l}\text { Mode of delivery of products must have variety of options including } \\
\text { outsourcing ontions }\end{array}$ & 1 & 2 & 3 & 4 & 5 \\
\hline 3 & A Faster mode of delivery must be available on demand & 1 & 2 & 3 & 4 & 5 \\
\hline 4 & $\begin{array}{l}\text { Variety of warehouses, distribution system must be available for delivery of } \\
\text { products }\end{array}$ & 1 & 2 & 3 & 4 & 5 \\
\hline 5 & Any order quantity from the customer can be satisfied & 1 & 2 & 3 & 4 & 5 \\
\hline 6 & The time and the cost implications of changing the delivery due dates & 1 & 2 & 3 & 4 & 5 \\
\hline 7 & Managing the cost of delay in meeting customers' orders & 1 & 2 & 3 & 4 & 5 \\
\hline
\end{tabular}

Use of IT tools for providing flexibility in SC (Information Flexibility)

\begin{tabular}{|l|l|l|l|l|l|l|}
\hline 1 & Efficient flow of information throughout the supply chain network & 1 & 2 & 3 & 4 & 5 \\
\hline 2 & Meeting varying information needs from existing information systems & 1 & 2 & 3 & 4 & 5 \\
\hline 3 & Integration of the existing information systems with other systems & 1 & 2 & 3 & 4 & 5 \\
\hline 4 & Reduce time and cost for exchanging the required information & 1 & 2 & 3 & 4 & 5 \\
\hline 5 & Update the IT tools and systems to support changing requirements & 1 & 2 & 3 & 4 & 5 \\
\hline
\end{tabular}

\section{Part C}

\section{SFs for Supply Chain Performance(SCP)}

Please indicate how the following performance measure compares with organizations competitors.

Likert Scale:

\begin{tabular}{|c|c|c|c|c|}
\hline Very weak & Weak & Moderate & Strong & Very Strong \\
\hline 1 & 2 & 3 & 4 & 5 \\
\hline
\end{tabular}

\section{Cost Performance}

\begin{tabular}{|l|l|l|l|l|l|l|}
\hline 1 & Return on Investment & 1 & 2 & 3 & 4 & 5 \\
\hline 2 & Return on Investment growth rate & 1 & 2 & 3 & 4 & 5 \\
\hline 3 & Market Share & 1 & 2 & 3 & 4 & 5 \\
\hline 4 & Share Growth & 1 & 2 & 3 & 4 & 5 \\
\hline
\end{tabular}

Logistics Performance

\begin{tabular}{|l|l|l|l|l|l|l|}
\hline 1 & Reduced warehouse costs. & 1 & 2 & 3 & 4 & 5 \\
\hline 2 & Reduced obsolescence. & 1 & 2 & 3 & 4 & 5 \\
\hline 3 & Faster order processing speed. & 1 & 2 & 3 & 4 & 5 \\
\hline 4 & Reduced inventory at all sites of supply chain. & 1 & 2 & 3 & 4 & 5 \\
\hline
\end{tabular}

Quality Performance \& Customer's Satisfaction

\begin{tabular}{|l|l|l|l|l|l|l|}
\hline 1 & Response time to customer query time & 1 & 2 & 3 & 4 & 5 \\
\hline 2 & Level of customer perceived value of product & 1 & 2 & 3 & 4 & 5 \\
\hline 3 & Level of service systems to meet particular customer needs & 1 & 2 & 3 & 4 & 5 \\
\hline
\end{tabular}

\section{End of Questionnaire}

